\title{
Dansk børnefjernsyn? - JA TAK
}

\section{Af Birgitte Holm Sørensen og Birgitte Tufte}

Det var med spanding, at børn og foraldre i 1988 imødeså TV2. Ville der med denne nye kanal komme spandende bøme- og ungdomsprogrammer, produceret af de mange unge producenter, som-med tillid til entreprisemodellen - stod klar i kulissen?

En sammenligning mellem borne-to pa DR og TV2 viser, at TV2 ikke har levet op til forventningeren. Tvertimod. TV2 tager ikke reelt børnene alvorligt og medtenker kun $i$ ringe omfang bơms udviklingstrin og erfaringer. Det gor derimod Danmarks Radio. Sävel kvantitativt som kvalitativt er der forskel mellem programfladen for borm og unge pa de to kanaler, men - set i lyset af udviklingen af børnefjernsyn pa de internationale kanaler, produceret over laveste kommercielle fallesnarners last - må man satte sin lid til dansk børne- og ungdomsin, som det ser ud $i$ dag pa DR, og som det KUNNE se ud pa TV2.

Medieforskningen i Danmarks Radio har unders $\varnothing$ gt forskelle og ligheder mellem DR og TV2 i et public service perspektiv og konkluderer, at whederne i programudbuddets overordnede sammensacting falder i gjnene«(Bentzon, 1991:26).

Dog viser den detaljerede programanalyse, som også er foretaget $i$ den naevnte unders $\phi$ gelse, at der er mklare forskelle i graden af public service«, whvor DR afgørende markerer sig med borneprogrammer, centrale faktaomrasder, dansk fiktion og mere public service i den indkøbte fremmedproduktion, hvoroverfor TV2 satser sin danske produktion indenfor underholdning «(Bentzon, 1991:26).

Det er hensigten med denne artikel at beskrive, hvori forskellene mellem børne- og ungdomsfjernsynet pa henholdsvis DR og TV2 kommer til udtryk. Artiklen bygger pa en uges analyse af borne- og ungdomsfjernsyn og ikke mindst pa jevnlig sening af den nevnte programflade - med en saerlig interesse for, hvordan TV2 siden etableringen den 1. oktober 1988 har sendt til born og unge. (Tufte,1988). Børn og unge ser ikke kun de programmer, der explicit er rettet mod dem, men vi har valgt primart at analysere det borne- og ungdomsty, som DR og 'TV2 selv definerer som rettet mod den naevnte målgruppe.

Vi fokuserer i det folgende pa borne og ung- domsudsendelser fra den 1.-7. november 1991. I den pågaldende uge viste DR 14 udsendelser, som var produceret for born og unge, med en samlet sendetid på i alt 10 timer og 20 minutter. 7 daglige udsendelser af 30 minutters varighed havde de yngste born som malgruppe. Disse udsendelser var placeret pa hverdage $\mathrm{kl}$. 18 og 1 ordag- søndag kl. 18.15 .5 udsendelser à en times varighed rettede sig mod de større børn og var placeret mandag-fredag kl. 17.45.1 time og 20 minutters udsendelse henvendte sig til unge og var placeret mandag aften kl.22.05. En udsendelse placeret lordag kl. 19 havde en bred malgruppe af alle born (og deres forzldre).

TV2 viste $i$ alt 9 udsendelser, som henvendte sig til born og unge. Den samlede sendetid udgjorde i alt 3 timer og 15 minutter, 5 udsendelser af $25,15,15,10$ og 35 minutters varighed havde de yngste born som mallgruppe. 2 udsendelser af $25 \operatorname{og} 25$ minutters varighed henvendte sig til born mellem ca. 4 og 12 arr. For de xeldste børn og unge var der 2 udsendelser, der varede henholdsvis 25 og 30 minutter. Udsendelserne var placeret lørdag fra kl. 16.45-18.00, søndag kl. 17.55-18.25 og tirsdag-fredag kl. 17.35 -18.00. Malgruppeangivelserne er hovedsageligt vores, når det galder TV2's produktioner, Malgruppeangivelserne er ikke defineret ved en fast sendetid for de sma eller store, og kun sjaldent i programomtalen. 


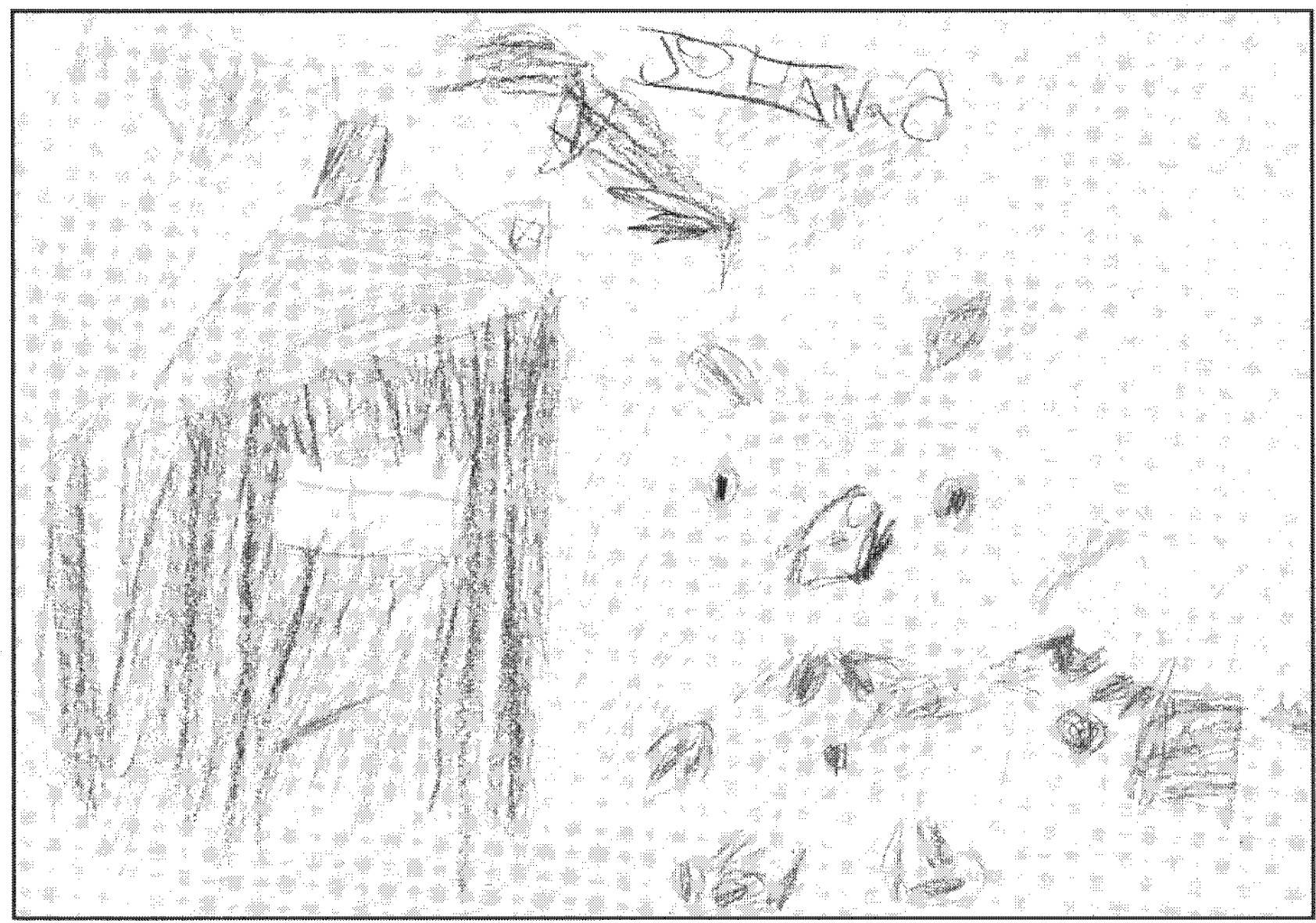

Børne-to gør indtryk pa børn, som har deres eget kreative udtryk for de populare programmer. Her er den 6-anige Johans opfattelse of DR's Bamses billedbog."

\section{Danmarks Radio - for de mindste}

DR's programflade for de mindste omfattede følgende: Fredagsbio kører nu på ellevte år med de to dukker Anna og Lotte. I ugens udsendelse var Lotte syg og blev passet af storesøster Anna. På et tidspunkt skulle Anna, udstyret med cykelhjelm, ud at cykle. Hun valtede og kom gradende ind med blod i ansigtet. Hun blev hjulpet af Lotte og måtte også ligge i sengen. De (og seerne) så derefter en eventyrfilm om en cykel, der, efter en tur pa lossepladsen, selv vender tilbage til sin ejermand, en lille dreng. Klip tilbage hos Anna og Lotte, hvor Anna stadig havde behov for hjalp og omsorg. Derefter endnu en film, en animeret modellervoks-dukkefilm om en lille pingvin, der hjalp sin post-far med at dele pakker ud. Igen tilbage hos Anna og Lotte, hvor sengen nu var blevet for lille til at numme dem begge. Dette løste Lotte ved at lave en seng på balkonen oven over - og de fik således en køjeseng.
Ude pâ noget med Palle, Polle og Ruth er en madventure «-præget føljeton, der forener det hverdagsagtige med det fantastiske, det utrolige med det hverdagsagtige og det voksne med det barnlige. I denne uge forsøger en af personerne, Sigurd, at stjale det magiske kamera, som kan bringe personerne forskellige steder hen.

I en analyserede episode af Bamses billedbog var Bamse, Kylling og Aske på fisketur sammen, men ikke uden problemer. Forst var Bamse "udenfor", og bagefter var det Askes tur til at vare mudenfor", da Bamse og Kylling fandt sammen om at laxe en bog.

Ramona er en engelsk produceret episodeserie om en pige, Ramona, på ca. 7 år. Denne uges episode handlede om, at Ramona fik en lillesøster, hvilket gav Ramona mange folelsesmassige problemer i forhold til sig selv, foraldrene og den nye lille.

Du store verden er en B\&U-produceret føljeton-serie om en pige Sharon, der bor på et 
børnehjem i Uganda. Moderen, som har børnehjemmet, sparer sammen til en bil. I ugens afsnit salger Sharon i hemmelighed grøntsager ved vejen for at skaffe penge. Hun bliver overfaldet al to drenge, der stjæler grontsagerne og pengene. Sharon svigter en aftale med moderen om at gå sammen med sin lillesøster. Hun fortaller ikke moderen hvorfor og straffes.

Honen og ... er et program, hvor der presenteres børnebø ger og hvor nogle af de bøger, der prasenteres ofte yderligere tematiseres i programmet, f.eks. ved rollespil.

Hvi' for en hand vil du ha er en direkte udsendelse med en studievart, der tager forskellige emner op eller viser nogle ting, som born kan lave - ofte af kreativ karakter. I denne udsendelse handlede det om hunde. I udsendelsen indgik også en Cirkeline-film om fotografering.

Hvis man ser pă nogle af de temaer, som publikummet af mindre born blev prasenteret for i løbet af ugen, tegner der sig følgende:

- følelsen af udelukkelse fra de andres leg og de argelser og aggressioner, det udløser - og over for dette nydelsen og glæeden ved at være sammen og opleve sammen.

- oplevelse af tilsidesattelse, folelsesmassig svigt fra foraldrenes side og jalousi, men også nare og varme follelser - f.eks. glaeden ved en ny lillesøster.

- skjult hjzelpsomhed, overskridelse af regler og spørgsmål om uretferdig straf.

- hjalpsomhed og opfindsomhed mht. løsning af problemer.

Tematisk rammer udsendelserne de temaer, som ofte prager de mindre børns liv. Udsendelsernes temaer er vasentlige for mindre børn, og måden de behandles på, rammer mindre børns måde at opleve, taenke og handle på. Det er karakteristisk for disse børneudsendelser, at der i meget hoj grad indgår børn og/ eller voksne og dyr, der optrader som bom. Børn eller børnelignende voksne, dyr eller dukker giver mulighed for identifikation $p \AA$ flere planer. Feks. giver Bamse og Kylling mulighed for genkendelse gennem det verbalsproglige, kropssproglige, motoriske og folelsesmassige.

Identifikationen kan ogsa ligge i konllikten enten i monsteret for konflikten eller $\mathrm{i}$ indhol- det af konllikten. - Bamseepisoden er eksempel på det forste og Ramona er eksempel på det sidste.

Personeme befinder sig ofte på barnets platform med hvad det indebæerer af brud på voksenverdenens normer for sprog og god opførsel, hvilket forstaerker identifikationen.

Generelt kan man sige, at de problemer og konflikter, der tages op, behandles nuanceret og uddybende. Konfliktbehandlingerne rummer et potentiale for folelsesmressig udvikling hos barneseeren. De folelsesmzessige aspekter, der appelleres til, er brede. P\& den ene side er der overfald, grad, fysisk og psykisk udelukkelse og straf, og pă den anden side er der glæede, hjzelpsomhed, varme og nzere relationer. Ikke kun på det indholdsmassige, men også på det formmassige plan fungerer udsendelserne. Formsproget er afpasset mindre børns perceptuelle udviklingstrin og den eksisterende viden om små borns reception af TV indgär tilsyneladende i tilrettelæggelsen af programmerne.

\section{Danmarks Radio - for de storre og for unge}

For de større børn omfattede programfladen i den pågreldende uge: Sig det med blomster, Den er go' og Den geologiske orm Georg Rutherfort. Disse tre udsendelser udgiorde fredagens program og rummede bla. en film om en miljogruppe, der gennemfører en miljøaktion og et program, hvor der blev presenteret gode bøger.

Zig-Zag er produceret af Arhus-redaktionen. I dette program er rammen et TV-studie med en rakke unge væerter, der på forskellig måde og med forskellige indfaldsvinkler præesenterer ugens emne og filmføljeton. Emnet i den pägaldende uge var unge og arbejdsulykker. De unge studieverter presenterede emnet ved hjaelp af facts, som de selv formidlede og ved at interviewe tre unge, der havde vaeret udsat for arbejdsulykker. Filmafsnittet, der omhandlede kxrlighed, blev vist, og bagefter diskuterede en gruppe af studievarterne filmen.

Handicapidret, som var denne uges udgave af B\&U Sport, rummede en rekke indslag om forskellige grene inden for handicapidraet. Indslagene rummede optagelser fra kampe og interviews med handicappede idratsudøvere.

Mellem himmel og jord var bygget op over cm- 
net hekse. Forst fortalte studievarten om $\mathrm{Ma}$ ren Spliid, som blev braendt som heks for 300 år siden. Derefter blev der vist. en tegnefilm Den markelige historie, som er et eventyr om en heks, der forvandler en frø til prins. Tilbage i studiet havde studievarten faet bes $\emptyset \mathrm{g}$ af Dannie Druehyld, en efter eget udsagn nulevende heks, der fortalte om sin tryllekraft og viste tryllekunstner. Emnet blev sluttet af med en tegnet collage over hekse og trolde m.m. fra serbokroatiske eventyr. Derefter blev der vist et afsnit fra den engelske-producerede børnehjemsserie Phoenix Hall om opklaringen af et tyveri. Til slut en kort humoristisk tegnefilm.

Troldespejlet er et orienteringsprogram om nye film. Der blev fortalt og vist klip fra nogle af efterårets nyheder. Bom $i$ andre lande var denne torsdag en reportage fra Brasilien, der skildrede gadebørnenes tilvarelse i Rio.

Denne aldersgruppe blev i løbet af ugen bl.a. prasenteret for følgende temaer:

- miljøproblemer med fokusering på handlemuligheder,

- ansvarlighed i forbindelse med arbejdsulykker og psyskiske, fysiske og sociale konsekvenser af arbejdsulykker,

- brud pa karlighedsforhold og valg af samvar med kxeresten fremfor ens kammerater,

- handicappedes problemer og formåen ved indretsudøven,

- overtro-og det overnaturlige,

- prøvelser på kammeratskabets styrke, når regler overtredes og ved kriminalitet.

I forhold til udsendelserne for de smă, er universet her mere omfattende. Programfladen for de små var i højere grad centreret om følelsesmassige forhold fra bornenes nare daglig. dag. For de lidt større børn var der også følelsesstof, som var identificerbart i forhold til de naere cirkler i hverdagen. Men ud over det folelsesmassige, som var nuanceret tematiseret, var der stof hentet udenfor hjem og skole. Der var samfundsmassige emner af politisk karakter og problemer fra den 3 . verden.

I sammenligning med programfladen for de mindre born, som er meget praget af fiktionsproduktioner, er det karakteristisk for udsendelserne for de storre børn, at de er mere pragede af det journalistiske omfattende bla. interviews og reportage.
Handicapidrat og Zig-Zag var eksempler på dette. I Handicapidrcet var det to voksne, der interviewede. Udsendelsen virkede lang trukken og lidt kedelig i sin form. I Zig-Zag udsendelsen om arbejdsulykker var det unge, der formidlede stoffet og det var unge, der interviewede. I forhold til malgruppen må denne udsendelse formodes at lungere langt bedre, bl.a. fordi de unge i Zig-Zag stiller spørgsmål udfra deres alder og baggrund, hvilket borneseeme sikkert bedre kan identificere sig med. Desuden er deres spørgsmal, - og øvrige fremstilling af emnet, praget af et folelsesmassigt engagement. Zig-Zag er iøvrigt den udsendelse, der ifølge Niels-Aage Nielsen (Nielsen 90:27) har det højeste seertal blandt disse fem borneudsendelser.

Transit $3 D$ er DR'ungdomsprogram sent mandag aften. Thansit produceres isæer af unge, hvoraf mange er uprofessionelle $i$ forhold til tv-produktion. Aftenens udsendelse bestod bl.a. af folgende: Drymmen on en familie - interviews med to unge, der var gaet fra hinanden efter at have sat to born i verden, opbrud om en pige der er gaet ud af 9 . klasse for at tage $\mathrm{p} a$ efterskole. Frysehuset - en reportage fra det stockholmske ungdomshus, der bla. rummer en rockskole, mulighed for at dyrke skateboard, bjergbestigning og andre sportsgrene, og Transmission - et musikvideopraesentationsprogram.

Transit startede i 1989 som et meget eksperimenterende ungdomsprogram. Konceptet til den forste "Transit«-rakke var inspireret af musikvideogenren og et ungdomsprogram på $B B C$. Udsendelsen er stadig på formplanet-tv meget eksperimenterende $i$ forhold til andet tw. Indholdsmassigt bliver der sedvanligvis găet meget tat på de interviewede, og man forsøger at komme i dybden. Det lykkes ofte, men ikke altid, hvilket aftenens indslag Opbrud var et eksempel pa. Transitkoden er anderledes og usæedvanlig. Forhåbentlig vil den også i fremtiden forblive ufxerdig = ikke fast og gentagende, og hele tiden mundervejs ", hvilket har praget forløbet hidtil. Transit er bade indholdsmaessigt og formelt en interessant nyskabelse, men man må nodvendigvis stille spørgsmalstegn ved, pă hwilken måde den fungerer $i$ forhold til forskellige grupper af unge?

Endelig skal næevnes Clausen og Hausgaard vender tilbage, som er et humoristisk program 
for børn og voksne om bl.a. børneopdragelse på baggrund af klip fra B \& U's børneudsendelser.

Konkluderende om Danmarks Radio's programflade for børn og unge i den pagaeldende uge og hele gruppen af born og unge, sa var der to for hele malgruppen, men nok med vagt på de mindre børn og børn i ca. 11-16 års alderen. Børnegruppen på ca. 7-10 år var knap så godt dxkket ind. Generelt mă siges, at personerne bag DR's B\&U programmer tager børn og unge alvorligt.

Udsendelserne bygger på et kendskab til de forskellige målgruppers kognitive udviklingstrin og de folelser og problemer, der optager de forskellige aldersgrupper. Gennemgå̉ende er der gode identifikationsmuligheder på person- og handleplan. Børne(ungdoms)synsvinklen kommer tydeligst til udtryk i udsendelser-

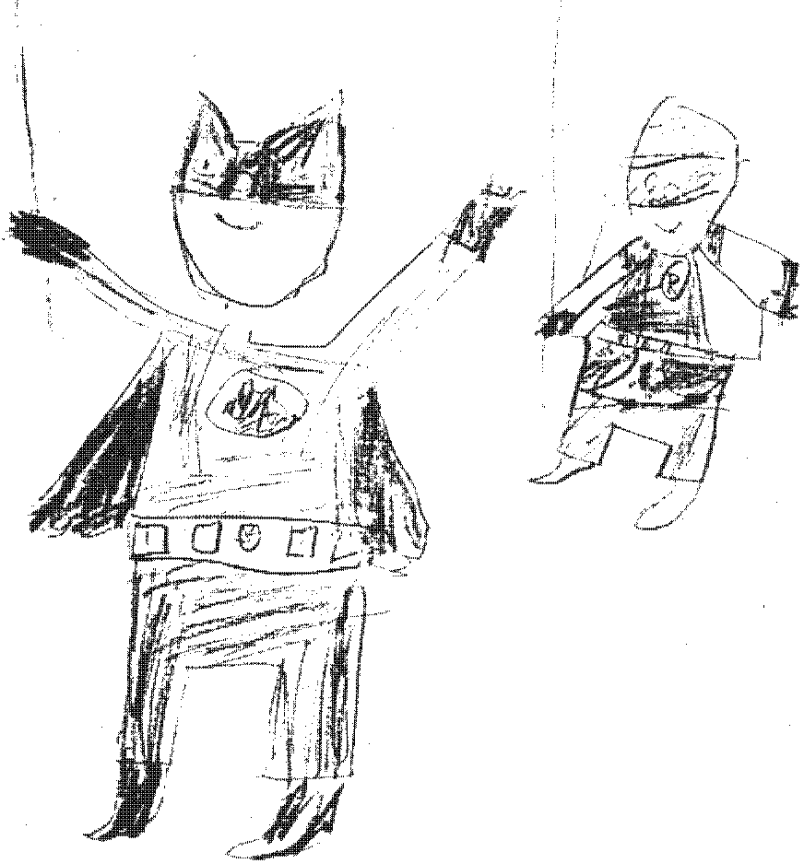

Den udenlandshe satter ogsa sine spor i borns fantasi. Dreng 8 dr, tegning of Batman. ne for de mindste, i en udsendelse som Zig-Zag og Transit. Der er i alle tre programflader nuancerede drenge- og pigeroller. Imidlertid er der i programfladen for de mindre børn overvagt af pigeroller og disse tegnes sardeles starke, med ringe muligheder for identifikation, mens drengerollerne er ferre og svagere tegnet, specialt set i forhold til forskoledrengenes voldsomme kropssprog og fysiske prestationsbehov.

\section{TV2: Bubber, 'Turtles og Trolderik for de små}

Ser man på TV2 er der tale om følgende borne og ungdoms-tv i de pågaldende uge:

$2 \times$ Ninja-padderne Turtles

Mini-TV-Dukke-TV for de mindste

Sytten-0-Dut-Bubber i badekamet

Kom narmere, vi har en drøm.

$2 \times$ Trolderiks Kvarter

Faktisk

- og endelig en tegnefilm.

I Ninja-paddeme Turtles er der tale om fire hovedpersoner, Michelangelo, Raphael, Donatello og Leonardo, som lever i New Yorks kloaknet, hvor de i sin tid er blevet udklakket og har vokset sig store takket vaere radioaktiv bestråling i spildevandet. En stor rotte, den rare Splinter, med baggrund i japansk krigskunst, har adopteret dem og oplaert dem i kampteknik.

De fire skildpadder kxmper for de små og forsvarsløse i New Yorks gader, og når de er voldelige, er det blot for at hjalpe. I modsatning til almindelige skildpadder er Ninja-padderne lynhurtige, og de lever af pizza. De fire padder og Splinter er de gode. Overfor dem stär de onde, personificeret ved bl.a. Schredder, Flaenseren, som er styret af videnskaben. Det er en videnskab, som er staerk og ondsindet, og som til stadighed udtrenker grimme ting i forhold til de gode.

Der er en gennemgäende kvinde i serien, den smukke og gode tv-nyhedsjournalist April O'Neill, som fungerer som hjalper for de fire padder. Hun er beskrevet som en dygtig tvjournalist, som ikke er gift, men har nok i mde fire grønne«, som hun siger. Dramaturgien i Turtles er klassisk med anslag, optrapning ud- 
løsning/udtoning. Det er karakteristisk, at anslaget ofte knytter an til målgruppens erfaringer.

Feks. presenteres vi $\mathrm{i}$ anslaget $\mathrm{i}$ den ene af de to udsendelser, som indgår $\mathrm{i}$ vores analysemateriale, for, at det er Leonardos fødselsdag og at han er så skuffet over, at hans venner tilsyneladende ikke har txenkt sig at fejre ham, at han lober vak. Umiddelbart derefter opstår der konflikter, så padderne må ud og slås. Men til slut, da alle konflikter er løst, ender det med, at Leonardos tre venner og April overrasker ham med en fodselsdag med lagkage og lys. At Turtles har haft så stor en succes er der mange grunde til. Bla. har der varet en utrolig flot markedsføring, så god, at legetøjsfigurerne var udsolgt i december 1990 - inden tvserien og filmen kom. Men successen skyldes utvivlsomt ogsa, at der knyttes an til bornenes egne erfaringer, som det er påvist ovenfor.

Turtles er aggressivt, handlingsmattet drengefjernsyn med stæerke effekter og påtrængende lydside, selv om pigerne også ser det. Med hensyn til, hvordan det fungerer for bornene, sa inspirerer det både til rollelege, tegninger og leg med legetøjsfigureme, men det er et problem, at det ikke er tekstet. Nogle småbørn, som endnu ikke kan laese, er meget opmarksomme, når der indledningsvis - i 3-4 satninger - fortalles om, hvad den pagaeldende episode skal handle om. Det er det eneste verbale redskab, de for til at orientere sig, når billederne går løs.

Mini-TV er amerikansk børne-TV med en rakke dukker, der arbejder på en TV-station. Dukkerne ligner de dukker, som kendes fra Muppet-show og Sesame Street. Tilsyneladende er der tale om borne-TV, men indholdsmassigt er det fjernsyn for større børn med en stzerk fokusering på indlering af lidt af hvert - og på et forholdsvis abstrakt plan.

Sytten-0-Dut er et program om "drengen* Bubber, der sidder i et badekar og taler i telefon med småbørn. Børn sender tegninger og sutter ind til Bubber. Nogle tegninger valges ud af Bubber og mommer i fjernsynet《. Det samme galder nogle heldige børn, som via telefonen kommer til at tale med Bubber og far lov til at synge en sang. De kan selv væelge, men det ser ud til, at der efterhanden - blandt de 3-4 årige - er konsensus om, at man kun kan synge Lille Peter Edderkop... Der er indlagt et filmindslag med Bubber, som besøger General Dryptud. De to oplever spaendende ting - i det pågældende tilfælde mødte de en guldgraver.

Udsendelsen afsluttes hver gang med, at bornene foran skxermen oplordres til at hjalpe

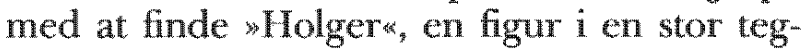
ning med mange mennesker, mens et bam i telefonen er den, som finder den. Bubbers badekar er baseret på små borns glaede ved gentagelsen som at synge den samme sang, at se tegninger og sutter, at lagge telefonen på for Bubber, at finde Holger etc. Bubber kommunikerer tilsyneladende direkte og xerligt til bornene, men der er tale om en pseudokommunikation. Hvor mange born sidder foran skermen og haber pa, at. netop deres tegning skal blive udvalgt? Og hvor mange born styrter sig over telefonen i hab om, at Bubber ringer dem op?

Bubbers Badekar har de kvaliteter, vi har gjort rede for, men det er også den slags fjernsyn, som hurtigt kommer til at kede ungerne. Om det så skyldes Bubbers talen ned til dem, pseudokommunikationen eller en for stor grad af gentagelse er ikke nemt at sige. Men faktum er, at det er den slags fjernsyn, hvor mange børn tilkendegiver deres interesse ved at se lidt og sa indimellem hoppe ned ad stolen og finde kassen med Lego frem i stedet for at se fjernsyn.

Trolderiks kuarter er en udsendelse, der som ramme har trolden Trolderik, der sidder og småsludrer om lidt af hvert - og ind imellem bliver irettesat af sin tipoldemor, som hanger på vaeggen. Sa følger en tegnefilm med nogle dyredukker, og udsendelsen slutter med, at Trolderik igen sludrer uden reference til den viste film - med moldew.

Temaet i en af analysematerialets Trolderiker er, at Trolderik ikke er en rigtig trold, fordi han ikke har horn, og det vil han meget gerne have. Olde har sagt, at han ikke en en rigtig trold, fordi han mangler horn, men det har Trolderik ikke til hensigt at tage sig af, fordi man kan ikke regne med hende - som han siger om "Olde $*$ "Hun laser ikke så mange boger efter hun er kommet i ramme-der er ikke plads til armene...

Som i de hidtil naevnte udsendelser er der en staerk overvagt af mand/drenge i Trolderik, selvom den har flere kvinder end de fleste andre udsendelser. De kvinder som figurerer er "Olde", en tåbelig gammel kvinde, som skalder ud hele tiden, men som heldigvis er handlingslammet og i glas og ramme. Desuden er der en kvinde i dukkefilmen, en stork, der taler med en skingrende stemme og er over-om sorgsfuld over for de andre dyr. 
Kort om den lille tegnefilm, som lå efter den ene Trolderik-udsendelse. Den handlede om en kanin, der løb efter en ulv. Der var tale om en lang forfølgelsesscene, tegnefilmens klassiker, hvor den lille prøver at far ram den store. Der var tale om ret voldelige metoder, hvor ulven hang i en telefonledning, som kaninen klippede over, så ulven endelig - langt om laenge, slog sig ihjel, mens der i underteksten stod: "Ring altid il lagevagten i god tid $*$. Voksenhumor, som ikke mange små børn forstår et kuk af.

\section{TV2: Manglende seriøsitet og brugsvardi?}

For de større børn omfattede programfladen i den pagaldende uge: Kom narmere, wi har en dram... er en u-landsserie, hvor fire skandinaviske piger besøger forskellige lande. I det pågaldende tilfelde drejede det sig om Campuchea. Faktisk er et dansk program for storre børn. Der er 3 personer, 2 mand og en kvinde, som undersøger og fortaller om forskellige emner. I den pägaldende udsendelse blev der feks. vist, hvordan man syr en jakke. Det blev ct oplysende indslag om skredderfaget med den humoristiske pointe, at jakken til sidst overhovedet ikke passede den person, som havde bestilt den. Desuden var der et indslag om ylbrygning. Faktisk er en blanding af underholdning og oplysning for storre born, en programtype, som TV2 åbenbart KAN lave.

Vi var mange, der i 1988 sprendt ventede på, hvordan børne- og ungdomsfjernsynet ville se ud pa TV2. Vi håbede på, at TV2 ville leve op til de kulturpolitiske og underholdningsmassige forpligtelser, som må formodes at ligge i etableringen af en ny tv-kanal, som ogsa er en public service kanal. Den forste tid var der meget for borne- og ungdomsudsendel ser, men gradvis er der blevet sendt mere borne- og ungdomstv. Hvordan kvaliten er fremgår forhåbentlig af ovennzevnte. At det imidlertid med de små midler, TV2 har - er muligt at lave dansk tv med rimelig brugsvaerdi for born og unge vidner Faktisk om.

Men det er et problem, at der tilsyneladende ikke lra TV2s side er seriøs interesse for mallgruppen. Der er for ofte tale om voksenproget tv, der ikke medtanker byrns udviklingstrin, erfaringer og behov for underholdning. $\mathrm{Og}$ taler vi om identifikation, en identifikation, hvor

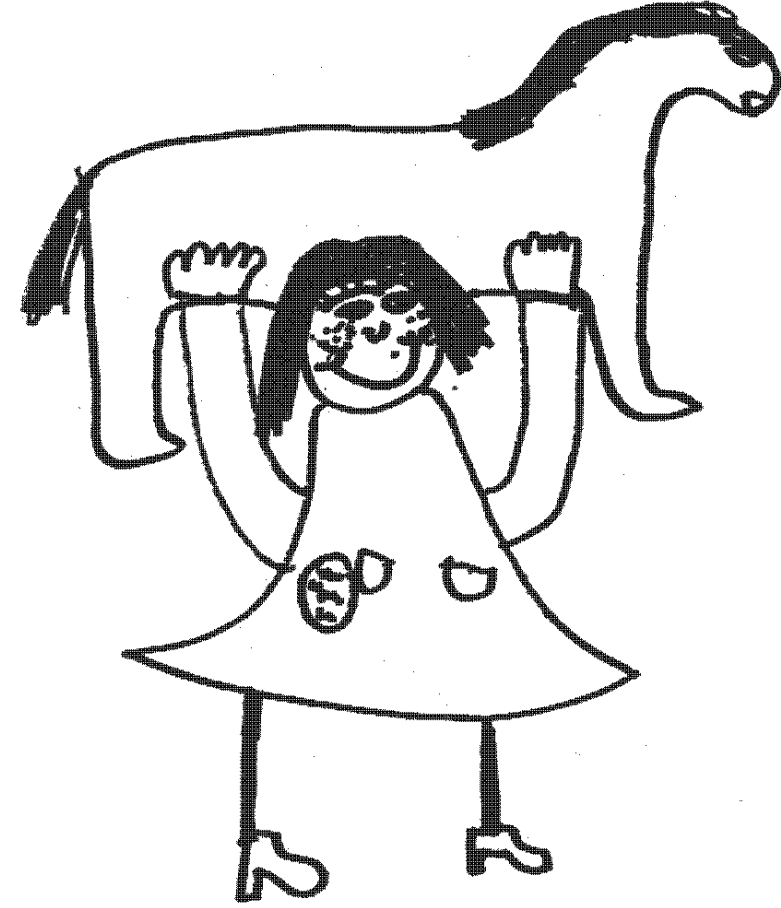

Godt nok er der ikhe sa mange piger i TV2's programmer. Men piger har ogsd deres adoler, der kan og vil noget. Pige pa 7, tegning af Pipi Langstrompe.

børn på forskellig alder skal have mulighed for genkendelse på det sociale og psykologiske niveau, må en gammel traver også trækkes ud af skabet. Desvaerre har det vist sig - efter analysen af TV2s børne- og ungdomsprogrammer, at det ikke er en gammel traver, men en ung hingst, nemlig kønsproblematikken. Som det vil vare fremgåtet af ovennavnte er der en massiv overvagt af mand og drenge i børneog ungdomslladen, og når kwinder endelig er synlige er det som $*$ April i Tuntles eller $*$ Olde i Trolderik. Måske er det ikke en bevidst programpolitik, men ...

\section{Konklusion}

I Danmark har vi med Danmarks Radio's børne- og ungdomsafdeling i mange år haft en tradition for godt børne- og ungdomstv. Det er nu tre ar siden, at TV2 begyndte at sende b $\phi r-$ neprogrammer. Hvordan har TV2's børne- og ungdomsprogrammer indskrevet sig i denne tradition? Kvantiteten af programmer har ve-" ret voksende i lobet af de tre ar. I ugen fra 1.-7. november var der som tidligere naevnt 3 timer og 15 minutters børne og ungdomsty. TV2's 
børneudsendelser udgør $5 \%$ af TV2's sendefalde fra kl. 17. Danmarks Radio's børneudsendelser udgør $11 \%$ af den samme sendeflade(Bentzon, 1991:13-15).

Pa det kvalitative niveau skulle det gerne fremgå af ovenstående, at der er stor forskel på de to kanaler. TV2's produktioner er for en stor del fremmedproducerede udsendelser, mens DR's i høj grad er egenproduktion. Disse programmer er specielt produceret for danske børn, og der opereres med snevre mâlgrupper. Dette bevirker, at man i tilretteloggelsen tager udgangspunkt i de specifikke psykiske, sociale og kulturelle forudsatninger, der karakteriserer hver målgruppe, hvilket har stor betydning for børnenes mulighed for identifikation og deres anvendelse af programmerne. Danmarks Radio's TV-programmer er populare hos børn (Nielsen, 1990:27,29,42).

TV2's udsendelser er i højere grad praget af en "generel børnepublikums«-tankegang, hvor man i mange tilfalde tilsyneladende indkøber børne- og tvprogrammer uden en dybere reflektion over, hvad der er for nogle børn og unge man sender til. Det gelder bade mht aldersgrupper og kulturelle forudsetninger.

Hvilke kvalitetskriterier skal man stille til borne og ungdomstv? Svaret er: De samme som til alt andet tv. John Carlsen drofter i Det gode fjernsyn (Carlsen,1984) forholdet mellem publikum, form, indhold, lyd og billede og påpeger, at den berømte kulturkløft er opstiet, fordi ingen fortalte de kulturradikale velmenende tv-producenter i fernsynets barndom, at det ikke var nok at tanke i form og indhold, men at man også må trenke i publikum.

Mht. DR så var de første børne-udsendelser ofte praget af det næunte kulturradikale menneskesyn. I 70'eme var der mange socialrealistiske børne- og ungdomsprogrammer. I de senere år er der sket en udvikling i retning af at producere børne- og ungdomstv, som băde er oplysende, astetisk flot og underholdende, og det ene behøver ikke tilsyneladende at udelukke det andet.

Børne- og ungdomsfjernsyn er tilsyneladende ikke kun det fjernsyn, som imidlertid sendes via DR og TV2 rettet mod born og unge. Med de mange satellitkanaler er der efterhånden et stort udbud af $t v$, som børn og unge ser. F.eks. er der pa Super Channel, TV3 og Children's Channel et stort udbud af tegnefilm. Dermed er de danske kanaler for alvor kommet i konkurrence om små og store seere.

Hvad angär børnefjernsynet er der en international tendens i retning af, at legetøjsindustrien bliver TV-producenter. (jfr. Turtles, Transformers etc.). Det vil bla. sige, at de mtegnefilm«, som sendes på satellitkanalerne, er "program length commercials for grønne padder, hvide ponyer, Barbie-dukker og "Transformers". I USA er legetøjsindustrien forlangst blevet den største producent af børnefjernsyn. Tom Engelhardt har redegjort for den udvikling fra begyndelsen af $80^{\prime}$ er ne (Engelhardt,1986), og uden at male fanden pa vaggen og påstă, at vi vil fa *amerikanske tilstande , så er tendensen ikke ukendt i Europa.

Som det er fremgaet lever Danmarks Radios borne- og ungdomsafdeling fortsat op til sit ry også internationalt - som producent af borne- og ungdomstv på et meget højt niveau. Til trods for denne artikels kritik af TV2s programflade for børn og unge må vi indrømme, at den kvalitativt ofte ligger over meget af det, man ser mange steder i udlandet og på satellitkanaleme. Med den udvikling, der har fundet sted siden TV2s start med stadig flere programmer for born og unge er der grund til en vis optimisme.

I forhold til fremtidens kaleidoskopiske tvkaos vil vi habbe, at borne- og ungdomsfjernsynet fra Danmarks Radio og TV2 fortsat udvikler sig, salledes at det ogsa fremover vil vare, hvad vi vil tillade os at kalde wdet mindst ringe børne- og ungdomsfjernsyn*.

\section{Litteratur}

Bentzon, Karl-Henrik, Niels-Aage Nielsen \& Erik Nordahl Svendsen: Ligheder og forkelle. En sammenligning af DR og TV2s programudbud, seertal og vurdering $\mathrm{i} 1990$ ud fra et public-service perspektiv. Danmarks Radio, Medieforskningen. Okt. 1991, ogsa trykt i Medie Kulur nr. 17, 1992.

Carlsen, John: Det gode fjomsyn. Centrum 1984.

Ingelhardt, Tom: The Shortcake Strategy in Gitin, Todd (ed): Watching Television, Pantheon Books. New York. 1986.

Nielsen, Niels-Aage: Born ser TV. Forskningsrapport IIr. $2 \mathrm{~B} / 90$

Tufte, Birgitte: Bqmenes juleantenner. Kronik i polit ken«22.12.1988.

Birgitte Holm Sørensen, adjunkt Danmarks Lxererhøjskole.

Birgitte Tufle, Lektor, Danmarks Larehøjskole. 